\title{
Risk Evaluation of Heavy Metals in Sediments of the Fish Farming Area in the Mediterranean Section of Lake Manzala
}

\author{
Beheary $\mathrm{MS}^{1^{*}}$, El-Matary FA ${ }^{2}$ \\ ${ }^{1}$ Environmental Science Department, Faculty of Sciences, Port Said University, Egypt. \\ ${ }^{2}$ National Institute of Oceanography and Fisheries, Suez branch, Egypt.
}

Received: 08 July 2015 / Accepted: 22 Auguat 2015

* Corresponding author: (email: beheary@ hotmail.com)

\begin{abstract}
To reveal the potential pollution characteristics of heavy metals in sediment of the fish farming area in the Mediterranean section of Lake Manzala, three indices of Enrichment factor (EF), Nemerow multi-factor, and Hakanson potential ecological risk factor have been used. The reference values for calculating these indices were the background levels in the same area. The averages of $\mathrm{EF}$ values are in the following order: $\mathrm{Cu}>\mathrm{Zn}>\mathrm{Cd}>\mathrm{Pb}$. The average of pollution indices (PI) and Contamination Factor $\left(\mathrm{C}^{\mathrm{i}} \mathrm{f}\right)$ descended in the order of $\mathrm{Fe}>\mathrm{Cu}>\mathrm{Zn}>\mathrm{Pb}>\mathrm{Cd}$. The NIPI values in sediments ranged from 0.36 to 15.57 indicating lightly polluted to severe or high level of pollution with an average of 6.68 (severe or high level of sediment pollution). The average contamination value $(\mathrm{Cd})$ was 28.12 , reflecting relatively high contamination degree. In terms of the mean potential ecological risk indices of the four types of heavy metals, the Eif arrayed is in the order of $\mathrm{Cu}>(\mathrm{Cd}>\mathrm{Pb})>\mathrm{Zn}$. $\mathrm{Cu}$ was the key influence factor to cause the potential ecological risk, and its Eif mean value was up to 37.63 with risk grade (medium). The scope of RI range was 36.25 and 92.96 with ecological risk levels slight and strong respectively.
\end{abstract}

Keywords: Enrichment Factor, Ecological Risk, Fish Farming, Mediterranean, Lake Manzala, Heavy Metals.

\section{Introduction}

Heavy metals are the most important pollutants that affect the ecosystem as they are persistent and resist degradation in normal conditions. Their toxicity appears after accumulating and exceeding level of indispensability and when they are not metabolized by the body and accumulate in the soft tissues. Metals are absorbed and accumulated on bottom sediments because of low solubility in water (Jain et al., 2008). Thus, the sediment can be a potential source of heavy metals launched in under water by natural and anthropogenic processes, where benthic biota or other organisms can ingest metal particles or contaminated water. This resulted in metals accumulating in their tissues and ultimately entering the food chain. Consequently, this could have a negative impact on human health (Yin et al., 2011). In addition to this, bottom sediments are sensitive indicators to monitor contaminants as they can act as a sink and a carrier of pollutants in the aquatic environment (Bai et al., 2011). For that, the 
sediment analysis plays an important role in assessing the state of pollution in the aquatic environment (Suresh et al., and Liang et al., 2012).

Indices of Pollution are a beneficial tool for analyzing, implementing, and transforming the environmentally raw information to authority and the public (Caeiro et al., 2005, and Qingjie et al., 2008). For these reasons, Enrichment Factor (EF), Hakanson (1980) ecological risk and the Nemerow multi-factor methods were used to evaluate the ecological hazards related to the five heavy metals analyzed in the contaminated sediments collected from the fish farms located in the Mediterranean section of Manzala Lake (Wang et al., 2013). In aquatic ecosystems, several environmental factors must be considered as chemical, physico-chemical, biological, and eco-toxicological parameters. All these variables must integrate and these indices must be applied to do it (Fiori et al., 3013).

Statistics have been used to evaluate the referenced and man-made influence of trace elements in lake sediments (Li et al., 2013).

The present work aims to determine the heavy metals concentrations $(\mathrm{Cd}, \mathrm{Fe}, \mathrm{Cu}, \mathrm{Pb}$ and $\mathrm{Zn})$ in sediments of the fish farms in the Mediterranean section of Manzala Lake and to evaluate the contamination degree of heavy-metal using the pollution indices (PI \& NIPI) and Enrichment Factor (EF). Also we aim to assess the sediments' toxicity using the single and integrated ecological risk indices.

\section{Methodology}

\section{Area of study}

The study fish farming is located in the eastern part of Lake Manzala in the Mediterranean section. Sampling sites are displayed in Figure 1. The lake is a shallow aquatic brackish system with depth ranged from 0.5 and $1.0 \mathrm{~m}$ (Shaheen \& Yosef, 1979). The study area receives its feeding from the Mediterranean through ElGamil and El Mussallas inlets (Rasmussen et al., 2009). The area was isolated from the main lake by the construction of a new coastal road. The area is now subdivided into small ponds for fish farming which is also practiced elsewhere within Lake Manzala (El Banna \& Frihy, 2008; and Ahmed et al., 2009). Other parts of this area have been developed for other uses including building and refuse disposals.

\section{Sampling}

Sediments were collected from 16 sites at El Mussallas area - the fish farming area in the Mediterranean section of Lake Manzala (Fig. 1). Sampling Locations were identified using GPS as described in Table 1. The sediment samples were oven dried, grounded, homogenized and sealed in clean polythene bags stored in a fridge till processing.

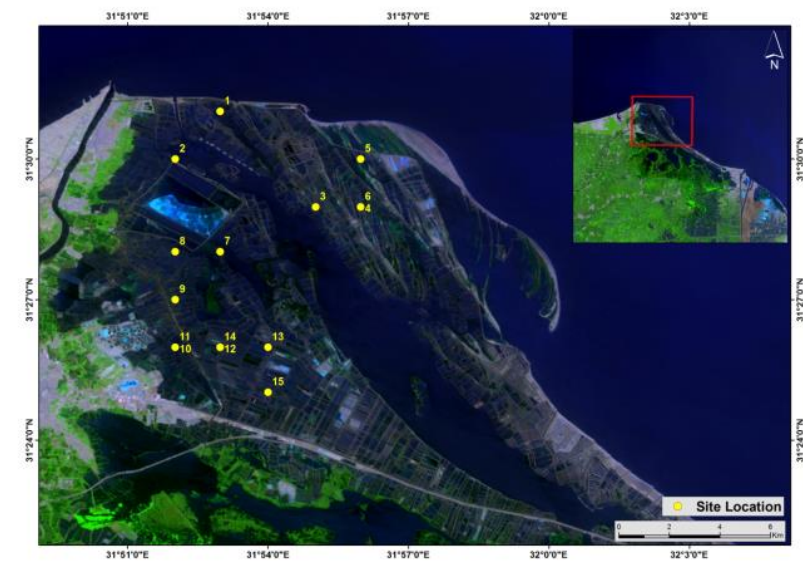

Fig. 1 Sampling sites from Lake Manzala.

\section{Heavy metal analysis}

Finding out the total heavy metals in sediments was measured according to UNEP/IAEA (1986). An exact weight of dry sample (about $0.5 \mathrm{~g}$ ) of sediment was completely digested in Teflon vessels using a mixture of $\mathrm{HNO}_{3}, \mathrm{HF}$ and $\mathrm{HClO}_{4}$ $(3: 2: 1 \mathrm{~V} / \mathrm{V})$. The final solution was diluted to 10 $\mathrm{ml}$ with distilled de-ionized water. All digested solutions were analyzed for heavy metals $(\mathrm{Cu}$, $\mathrm{Cd}, \mathrm{Pb}, \mathrm{Zn}$, and $\mathrm{Fe}$ ) by using atomic absorption spectrophotometer (Shimadzu AA-6800) and results expressed as $\mathrm{mg} / \mathrm{kg}^{-1}$ dry wt.

\section{Methods of heavy-metal pollution assessment}

\section{Enrichment factor $(E F)$}

Enrichment factor (EF) was developed by Taylor (1964). It is one of the indicators most often used for estimating anthropogenic inputs (GonzálesMacías et al,. 2006, Çevik et al., 2009, and Lourĩno-Cabana et al., 2011). This technique based on the hypothesis that, in the natural sedimentation conditions, there is a linear relationship between the reference elements (RE) and other elements if RE concentration changed with a factor the concentration of the other elements change also with the same factor (El- 
Gharabawy et al., 2011). The EF ratio can be used as an indicator of pollution by comparing the concentrations of identified metals with the reference levels of these metals in sediments from local or worldwide lakes. It's important to use the background or reference values of a local sediments as it can be better for comparison. The commonly used metals for are $\mathrm{Al}$ (Kwokal et al., 2002, and Zhang et al., 2009) and $\mathrm{Fe}$ (Ghrefat et al., 2006 and Çevik et al., 2009). We use Fe as a reference element to identify natural from anthropogenic components. The reference values were obtained from site 16 (Fig. 1). The concentrations of various elements in this site were nearly the lowest among those sampling sites. The EF is defined as follows (Li et al., 2013 and Ra et al. 2014):

$$
\mathrm{EF}=\frac{\mathrm{M}_{\mathrm{s}} / \mathrm{Fe}_{\mathrm{s}}}{\mathrm{M}_{\mathrm{r}} / \mathrm{Fe}_{\mathrm{r}}}
$$

Where $\mathrm{M}_{\mathrm{s}}$ and $\mathrm{Fe}_{\mathrm{s}}$ is the measured value of a metal and its $\mathrm{Fe}$ value for each site, $\mathrm{M}_{\mathrm{r}}$ and $\mathrm{Fe}_{\mathrm{r}}$ is the measured value of a metal and its $\mathrm{Fe}$ value for site 16 (reference site). The EF value was differentiated to seven classes according to Taylor (1964) in Table 2.

\section{Nemerow multi-factor index method}

The sub-index can be used to calculate the single factor and multi-factor comprehensive pollution indices of sediment heavy metals. The situation at Manzala Lake was analyzed based on the subindex, the single factor contamination index, and multi-factor comprehensive contamination index (Soldecilla et al., 1992, and Li et al., 2003). The comprehensive contamination index is able to highlight the effects of high concentrations of contaminants on environmental sediment quality. Therefore, the comprehensive pollution index provides a more scientific representation of sediment contaminants and sediment environmental quality. Nemerow integrated pollution index (Yang et al., 2011) was attributed to each sample (Wang et al., 2013).

Table 1. The sampling sites description and its GPS locations.

\begin{tabular}{|c|c|c|c|c|c|c|}
\hline \multirow[b]{2}{*}{ sites } & \multicolumn{4}{|c|}{ locations } & \multirow{2}{*}{ elevation(m) } & \multirow{2}{*}{ Description of the sampling sites } \\
\hline & $\mathrm{E}$ & & $\mathrm{N}$ & & & \\
\hline 1 & $31^{\circ}$ & $52.92^{\prime}$ & $31^{\circ}$ & $30.980^{\prime}$ & 8 & $\begin{array}{l}\text { Near the new harbor that feeding the lake from the } \\
\text { Mediterranean se) within } 2 \mathrm{~km} \text { away from ezbet elborg. }\end{array}$ \\
\hline 2 & $31^{\circ}$ & $52.33^{\prime}$ & $31^{\circ}$ & $30.249^{\prime}$ & 7 & Open area near to the farm own to the governorate. \\
\hline 3 & $31^{\circ}$ & $54.972^{\prime}$ & $31^{\circ}$ & $28.750^{\prime}$ & 7 & $\begin{array}{l}\text { The beginning of the government channel (feed opening } 6 \\
\mathrm{~km} \text { from ezbet elborg. }\end{array}$ \\
\hline 4 & $31^{\circ}$ & $55.543^{\prime}$ & $31^{\circ}$ & $29.393^{\prime}$ & 6 & Middle of the government Channel. \\
\hline 5 & $31^{\circ}$ & $55.717^{\prime}$ & $31^{\circ}$ & $30.255^{\prime}$ & 4 & $\begin{array}{l}\text { The beginning of El karaka feeding channel (privet farm } \\
\text { own to mohammed shetta). }\end{array}$ \\
\hline 6 & $31^{\circ}$ & $55.718^{\prime}$ & $31^{\circ}$ & $30.257^{\prime}$ & 4 & $\begin{array}{l}\text { Middle of El karaka feeding channel. The feeding stop as } \\
\text { result of siltation processes. }\end{array}$ \\
\hline 7 & $31^{\circ}$ & 53. $242^{\prime}$ & $31^{\circ}$ & $28.269^{\prime}$ & 7 & Privet farm own to Mohammed hamdy. \\
\hline 8 & $31^{\circ}$ & $52.105^{\prime}$ & $31^{\circ}$ & $27.674^{\prime}$ & 2 & $\begin{array}{l}\text { Middle of el arbeen channel (linked between government } \\
\text { channel and el rattama channel) }\end{array}$ \\
\hline 9 & $31^{\circ}$ & $51.693^{\prime}$ & $31^{\circ}$ & $27.313^{\prime}$ & 5 & $\begin{array}{l}\text { The connection between el arbeen channel and el rattama } \\
\text { channel. }\end{array}$ \\
\hline 10 & $31^{\circ}$ & $52.27^{\prime}$ & $31^{\circ}$ & $26.472^{\prime}$ & 1 & Middle of el rattama channel. \\
\hline 11 & $31^{\circ}$ & $52.274^{\prime}$ & $31^{\circ}$ & $26.287^{\prime}$ & 6 & The beginning of the young graduates' channel. \\
\hline 12 & $31^{\circ}$ & $53.239^{\prime}$ & $31^{\circ}$ & $26.350^{\prime}$ & 3 & Middle of The young graduates channel \\
\hline 13 & $31^{\circ}$ & $53.8^{\prime}$ & $31^{\circ}$ & $25.844^{\prime}$ & 9 & Private farm own to Hassan saqr. \\
\hline 14 & $31^{\circ}$ & $52.927^{\prime}$ & $31^{\circ}$ & $25.614^{\prime}$ & 10 & Private farm own to El beheary. \\
\hline 15 & $31^{\circ}$ & $53.59^{\prime}$ & $31^{\circ}$ & $24.858^{\prime}$ & 7 & End of The young graduates' channel. \\
\hline 16 & $31^{\circ}$ & $52.813^{\prime}$ & $31^{\circ}$ & $24.528^{\prime}$ & 8 & Feeding channel from the southern part of Lake Manzala. \\
\hline
\end{tabular}

The single contamination index (PI) was defined as follows:

$$
\mathrm{PI}=\mathrm{C}_{\mathrm{s}} / \mathrm{S}_{\mathrm{r}}
$$

where $\mathrm{C}_{\mathrm{s}}$ is the measured value for one metal, and $S_{r}$ is the background or reference value. The sediment is not contaminated when $\mathrm{PI} \leq 1$ but is contaminated when PI $>1$, and the higher the PI the more serious the sediment contamination.

The Nemerow multi-factor index for a site is defined as follows: 


$$
\mathrm{NIPI}=\left(\mathrm{PI}^{2}{ }_{\text {i ave }}+\mathrm{PI}^{2}{ }_{\mathrm{i} \text { max }} / 2\right)^{1 / 2}
$$

Where $\mathrm{PI}^{2}{ }_{\mathrm{i} \text { max }}$ and $\mathrm{PI}^{2}{ }_{\mathrm{i} \text { ave }}$ are the maximum and mean contamination factor (PI) value of each heavy metal (Wang et al., 2013 and Jiang, 2014). The NIPI is classified as in Table 3.

Table 2. The classification of EF value was defined in seven classes according to (Taylor, 1964 and Ra et al. 2014).

\begin{tabular}{c|l}
\hline EF classes & Sediment quality \\
\hline EF $<1$ & No enrichment \\
$1-3$ & Minor \\
$3-5$ & Moderate \\
$5-10$ & Moderately severe \\
$10-25$ & Severe \\
$25-50$ & Very severe \\
$>50$ & Extremely severe \\
\hline
\end{tabular}

Table 3. Classification criteria for the comprehensive soil sediment assessment (Yang et al., 2010, and Jiang, 2014).

\begin{tabular}{c|l|l}
\hline $\begin{array}{c}\text { Grade } \\
\text { division }\end{array}$ & \multicolumn{1}{|c|}{ NIPI } & Contamination level \\
\hline 1 & NIPI $\leq 0.7$ & $\begin{array}{l}\text { non-pollution } \\
\text { warning line of } \\
2\end{array}$ \\
& $0.7<\mathrm{NIPI} \leq 1$ & pollution \\
3 & $1<\mathrm{NIPI} \leq 2$ & low \\
4 & $2<\mathrm{NIPI} \leq 3$ & moderate \\
5 & NIPI $>3$ & sever or high level \\
\hline
\end{tabular}

\section{Potential Ecological Risk Index (PERI)}

The environmental behavior of heavy metal contaminants in sediments was assessed by risk index method. The assessment was able to reflect the effects of various contaminants and to reveal the comprehensive influence of multiple contaminants in a particular environment. At present, the Hakanson method is the most scientific and comprehensive approach to assessing heavy metal contamination in sediments. This index was widely used and had great influence at international level (Fan et al., 2002 and Guo et al., 2010). The method was defined as follows:

\section{Contamination Factor $\left(C_{f}^{i}\right)$}

Contamination Factor $C_{f}^{i}$ is defined as follows

$$
\mathrm{C}_{\mathrm{f}}^{\mathrm{i}}=\mathrm{C}_{\text {sample }}^{\mathrm{i}} / \mathrm{C}_{\text {reference }}^{\mathrm{i}}
$$

Where $C_{f_{f}}$ is contamination coefficient of a certain metal in sediment, which can display the contamination modality in the studied area, but cannot determine the extent of environmental and biological risks in the region. $\mathrm{C}_{\text {smple }}^{\mathbf{i}}$ is the concentration of metals in sediment samples. $\mathrm{C}_{\text {reference }}^{\mathrm{i}}$ is the background or reference values of metals goatherd from previous research (AbdelBaky et al., 1998, Madkour 2005, Saeed et al., 2008, and El-Serehy et al., 2012). The classifications according to $\mathrm{C}_{\mathbf{f}} \mathbf{i}$ results were summarized in Table 4.

The comprehensive contamination measure $\left(\mathrm{C}_{\mathrm{d}}\right)$ for one area is the summation of all $\mathrm{C}_{\mathrm{f}}^{\mathrm{i}}$

$$
\mathrm{C}_{\mathrm{d}}=\sum \mathrm{C}_{\mathrm{f}}^{\mathrm{i}}
$$

Five heavy metals $(\mathrm{Fe}, \mathrm{Pb}, \mathrm{Cu}, \mathrm{Zn}$, and $\mathrm{Cd}$ ) are investigated. $C_{d}$ classification was summarized in Table 5.

Table 4. Classification criteria for the contamination coefficient $\left(\mathrm{C}_{\mathrm{f}}^{\mathrm{i}}\right)$ (Yang et al., 2010, and Jiang et al., 2014).

\begin{tabular}{c|l}
\hline Contamination Factor & Classification \\
\hline $\mathrm{C}_{\mathrm{f}}^{\mathrm{i}}<1$ & Low \\
$1 \leq \mathrm{C}_{\mathrm{f}}^{\mathrm{i}}<2$ & light \\
$2 \leq \mathrm{C}_{\mathrm{f}}^{\mathrm{i}}<3$ & Moderate \\
$\mathrm{C}_{\mathrm{f}}^{\mathrm{i}} \geq 3$ & heavy \\
\hline
\end{tabular}

Table 5. Classification criteria for the integrated pollution degree $\left(\mathrm{C}_{\mathrm{d}}\right)$ (Fu et al., 2009 and Jiang et al., 2014).

\begin{tabular}{c|l}
\hline Degree of contamination Factor & Classification \\
\hline$C_{d}<5$ & Low \\
$5 \leq C_{d}<10$ & Moderate \\
$10 \leq C_{d}<20$ & relatively \\
& high \\
$C_{d} \geq 20$ & Very high \\
\hline
\end{tabular}

The single ecological risk index $\left(E_{f}^{i}\right)$

The formula for potential ecological risk index for the single heavy metal pollution:

$$
\mathrm{E}_{\mathrm{f}}^{\mathrm{i}}=\mathrm{C}_{\mathrm{f}}^{\mathrm{i}} \times \mathrm{T}_{\mathrm{f}}^{\mathrm{i}}
$$

Where $T_{f}^{i}$ is the toxic response factor of the single heavy metal. The toxic response factor represents the potential hazard of heavy metal contamination by indicating the toxicity of particular heavy metal and the environmental sensitivity to contamination. The toxic response factor was determined according to the "elements 
abundance principle" and the "elements release principle". According to the standardized toxic response factor proposed by Hakanson (1980) $\mathrm{Cd}, \mathrm{Hg}, \mathrm{As}, \mathrm{Pb}, \mathrm{Cr}, \mathrm{Cu}, \mathrm{Zn}$, and $\mathrm{Ni}$ have toxic response factors of $30,40,10,5,2,5,1$, and 5 , respectively.

\section{The potential ecological risk index (RI)}

The formula for the ecological risk index for multi heavy metals:

$$
R I=\sum E_{f}^{i}
$$

Due to the difference in pollutant types and quantity, the present study adjusted the grading standard of heavy metals' ecological risk indices based on the types and quantity of pollutants $(\mathrm{Li}$ et al., 2012). The standards of potential risk index of metals in sediment were displayed in Table 6.

Table 6. The corresponding grading standards for ecological risk index (Fu et al., 2009 and Jiang et al., 2014)

\begin{tabular}{l|l|l|l}
\hline \multicolumn{1}{c|}{$\mathrm{E}_{\mathrm{f}}^{\mathrm{i}}$} & Classification & \multicolumn{1}{c|}{$\mathrm{RI}$} & Classification \\
\hline $\mathrm{E}_{\mathrm{f}}^{\mathrm{i}}<30$ & slight & $\mathrm{RI}<40$ & slight \\
$30 \leq \mathrm{E}_{\mathrm{f}}^{\mathrm{i}}$ & medium & $40 \leq \mathrm{RI}<$ & medium \\
$<60$ & & $80 \leq$ & \\
$60 \leq \mathrm{E}_{\mathrm{f}}^{\mathrm{i}}$ & strong & $80 \leq \mathrm{RI}<$ & strong \\
$<120$ & & 160 & \\
$120 \leq \mathrm{E}_{\mathrm{f}}^{\mathrm{i}}$ & Very strong & $160 \leq \mathrm{RI}<$ & Very strong \\
$<240$ & & 320 & \\
$\mathrm{E}_{\mathrm{f}}^{\mathrm{i}} \geq 240$ & Extremely & $\mathrm{RI} \geq 320$ & - \\
& strong & & \\
\hline
\end{tabular}

\section{Data analysis}

Descriptive statistics e.g. standard deviation, maximum, minimum, average and Pearson correlation coefficient are performed using SPSS version 18.

\section{Results and Discussion}

Comparison of heavy-metal concentrations in sediments of Manzala Lake with background values

The concentrations of heavy metals in the lake sediments, the background, and the international guidelines values are listed in Table 7. The mean concentrations of $\mathrm{Cu}, \mathrm{Cd}, \mathrm{Pb}$ and $\mathrm{Zn}$ were lower than the PLE and ERM international guidelines. The mean values of $\mathrm{Cd}$ were lower than the background values that recorded by Madkour (2005), El-Serehy et al., (2012), Abdel-Baky et al. (1998), and Saeed et al., (2008). The mean concentrations of $\mathrm{Cu}$ were higher than the background values recorded by Madkour (2005), El-Serehy et al., (2012), and Abdel-Baky et al. (1998) and lower than the values recorded by Saeed et al., (2008). The recorded values for $\mathrm{Zn}$ were the same as $\mathrm{Cu}$ except that $\mathrm{Zn}$ was nearly equal to the values recorded by Abdel-Baky et al. (1998). While, the mean values of $\mathrm{Pb}$ was higher than the background values recorded by Madkour (2005) and Abdel-Baky et al. (1998), it was lower than the values recorded by El-Serehy, et al., (2012), and Saeed et al., (2008). The mean concentrations of $\mathrm{Fe}$ were higher than that recorded by Saeed et al., (2008) and lower than that recorded by El-Serehy, et al., (2012).

\section{The enrichment factor $(E F)$}

The enrichment factor (EF) for the four metals $(\mathrm{Cd}, \mathrm{Cu}, \mathrm{Zn}, \mathrm{Pb})$ was calculated based on the five element $(\mathrm{Fe})$ to evaluate the anthropogenic contribution to heavy metals in sediments and is shown in Figure 2. The average of EF values for $\mathrm{Cd}$ (1.22), $\mathrm{Cu}$ (1.92) and $\mathrm{Zn}$ (1.62) were in the range of 1-3(minor enrichment) and the average $\mathrm{EF}$ value for $\mathrm{pb}(0.99)$ was in the range of $\mathrm{EF}<1$ (No enrichment).The $\mathrm{EF}$ values for $\mathrm{Cd}$ ranged from 0.88 (No enrichment) at site (13) to1.55 (minor enrichment) at site (8). The EF values for $\mathrm{Cu}$ were highly variable at sampling sites, ranging from 1.21 to 3.44 indicating a minor enrichment (EF class 1-3) to moderate enrichment (EF class 3-5). Zn ranged from 1.06 to 2.41 indicating minor enrichment (EF class 1-3). The highest $\mathrm{EF}$ value for $\mathrm{Pb}$ (1.79) was observed at site (2) indicating minor enrichment (EF classes 1-3). Metal contamination level is arranged as follow: $\mathrm{Cu}>\mathrm{Zn}>\mathrm{Cd}>\mathrm{Pb}$.

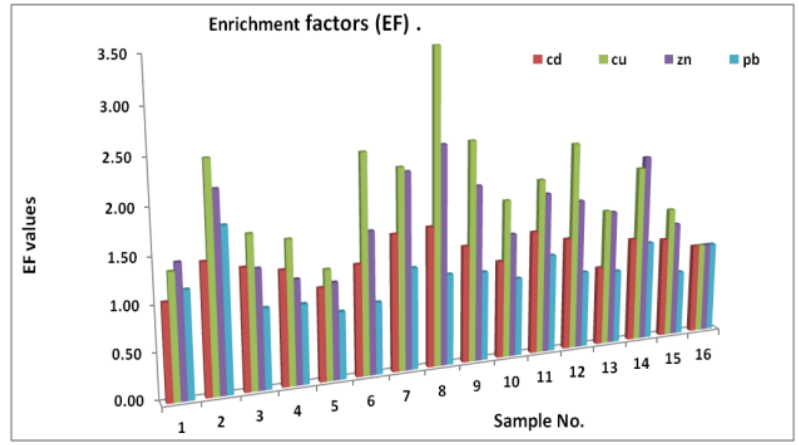

Fig. 2 EF calculated for some heavy metals in polluted sediments of Manzala Lake. 
Table 7. Heavy metal ( $\mathrm{mg} \mathrm{kg}^{-1}$ dry wt.) with the range of reference and the International guidelines values.

\begin{tabular}{|c|c|c|c|c|c|}
\hline \multirow{2}{*}{ Sites } & \multicolumn{5}{|c|}{ Concentration in sediments ( $\mathrm{mg} \mathrm{kg}^{-1}$ dry wt.) } \\
\hline & $\mathrm{Cd}$ & $\mathrm{Cu}$ & $\mathrm{Zn}$ & $\mathrm{Pb}$ & $\mathrm{Fe}$ \\
\hline 1 & 0.88 & 15 & 43.28 & 21.06 & 516 \\
\hline 2 & 1.2 & 27.38 & 64.84 & 32.5 & 520.8 \\
\hline 3 & 1.1 & 18.28 & 38.68 & 15.84 & 515.2 \\
\hline 4 & 1.04 & 17.2 & 33.94 & 15.72 & 514.8 \\
\hline 5 & 0.84 & 13.16 & 31.38 & 13.26 & 511.8 \\
\hline 6 & 1.02 & 26.4 & 46.74 & 14.34 & 517 \\
\hline 7 & 1.26 & 24.44 & 64.72 & 20.4 & 520 \\
\hline 8 & 1.3 & 38.24 & 72.72 & 18.42 & 523.4 \\
\hline 9 & 1.08 & 26.76 & 57.96 & 17.92 & 519.8 \\
\hline 10 & 0.9 & 19.18 & 40.8 & 15.72 & 517.2 \\
\hline 11 & 1.14 & 21.34 & 53.12 & 19.68 & 519.4 \\
\hline 12 & 1.04 & 25.26 & 49.56 & 15.38 & 518.6 \\
\hline 13 & 0.72 & 16.44 & 44 & 14.6 & 510.8 \\
\hline 14 & 0.96 & 21.38 & 61.54 & 19.76 & 514.8 \\
\hline 15 & 0.92 & 15.82 & 37.82 & 12.82 & 512.8 \\
\hline 16 & 0.82 & 10.84 & 29.4 & 17.84 & 510.4 \\
\hline Max & 1.3 & 38.24 & 72.72 & 32.5 & 523.4 \\
\hline Min & 0.72 & 10.84 & 29.4 & 12.82 & 510.4 \\
\hline Average \pm SD & $1.01 \pm 0.16$ & $21.07 \pm 6.85$ & $48.16 \pm 13.13$ & $17.83 \pm 4.67$ & $516.43 \pm 3.79$ \\
\hline \multicolumn{6}{|l|}{ Reference values / $\mathrm{mg} \mathrm{kg}^{-1}$ dry wt. } \\
\hline Madkour, (2005). & 3.2 & 2.8 & 14.2 & 2.5 & - \\
\hline El-Serehy, et al., (2012) & 1.9 & 7 & 32.5 & 21 & 1918.7 \\
\hline Saeed et al., (2008). & 84.8 & 315.36 & 432.16 & 134.6 & 33.39 \\
\hline Abdel-Baky et al. (1998). & 1.36 & 7.89 & 48.42 & 14.05 & - \\
\hline \multicolumn{6}{|c|}{ International guidelines ( $\mu \mathrm{g} / \mathrm{g}$ dry $\mathrm{wt}$.$) :$} \\
\hline Persaud et al. 1990. & $0.6-10$ & $16-110$ & $120-820$ & $31-250$ & - \\
\hline Canadian TLE-PLE. & $0.7-4.2$ & $18.7-108$ & $124-271$ & $30.2-112$ & - \\
\hline Wisconsin TLE-PLE. & $0.99-5.0$ & $32-150$ & $120-460$ & $36-130$ & - \\
\hline FlemishTarget value-Limit value. & $2.5-7$ & $20-100$ & $160-500$ & $70-350$ & - \\
\hline NOAA guidelines ERL- ERM. & $1.2-9.6$ & $34-270$ & $150-410$ & $46.7-218$ & - \\
\hline
\end{tabular}

ERL: Effects Range-Low; ERM: Effects Range-Median; TEL: Threshold Effect Level; PEL: Probable Effect Level.

\section{Nemerow integrated pollution index (NIPI)}

The single contamination index (IP) varied greatly among heavy metals. The PI values for Cd ranged from 0.23 at site (13) to 0.41 at site (8) indicating that the sediment was uncontaminated by $\mathrm{Cd}$. The sediment was strong to very strongly contaminated with $\mathrm{Cu}$, as PI values were ranged from 3.87 (site 16) to 13.66 (site 8). While, the maximum PI value of $\mathrm{Zn} \mathrm{(5.12)} \mathrm{was} \mathrm{recorded} \mathrm{at}$ site (8) indicating strongly contaminated sediment, the lowest (2.07) were recorded at site (16) indicating moderately contaminated sediments. The range of IP value for $\mathrm{Pb}$ were 1.03 (site 15 ) to 2.60 (site 2) indicating low to moderately contaminated sediment. Also, The PI values for $\mathrm{Fe}$ were ranged from 15.29 at site (16) to 15.68 at site (8) indicating very strong level of sediment pollution. As a result, site (8) show the highest PI values among all sites for the all measured elements while, site 16 is the lowest. The results showed that the average of PI descended in the order of $\mathrm{Fe}(15.47)>\mathrm{cu}$ (7.53) $>\mathrm{Zn}(3.39)>\mathrm{Pb}(1.43)>\mathrm{Cd}$ (0.32). The NIPI values in the lake sediments ranged from 0.36 to 15.57 indicating slightly polluted $(\mathrm{NIPI} \leq 0.7)$ to sever or high level of pollution (NIPI>3) with an average of 6.68 (sever or high level of sediment pollution). The results of PI and NIPI of heavy metals in sediment of Manzala Lake are expressed in Figures 3 and 4.

\section{Contamination coefficient analysis of heavy metals in the sediments}


According to Hakanson's method, degree of pollution and ecological risk are analyzed by the use of potent ecological risk index method (Puente et al., 2008 and $\mathrm{Fu}$ et al., 2009). The contamination coefficient $\left(\mathrm{C}_{\mathrm{f}}^{\mathrm{i}}\right)$ has the same values of PI calculated above. The order of $\mathrm{C}_{\mathrm{f}}^{\mathrm{i}}$ for the 5 heavy metals was $\mathrm{Fe}>\mathrm{Cu}>\mathrm{Zn}>\mathrm{Pb}>\mathrm{Cd}$ (Fig. 5). The $\left(\mathrm{C}_{\mathrm{d}}\right)$ value was determined as the sum of all $\mathrm{C}_{\mathrm{f}}^{\mathrm{i}}$ of one site. The $\mathrm{C}_{\mathrm{d}}$ ranged from 22.91 at site (16) to 36.33 at site (8) indicating relatively high to very high contamination (Fu et al., 2009). The average value of $C_{d}$ were 28.12 , reflecting relatively high contamination degree (Fig. 6).

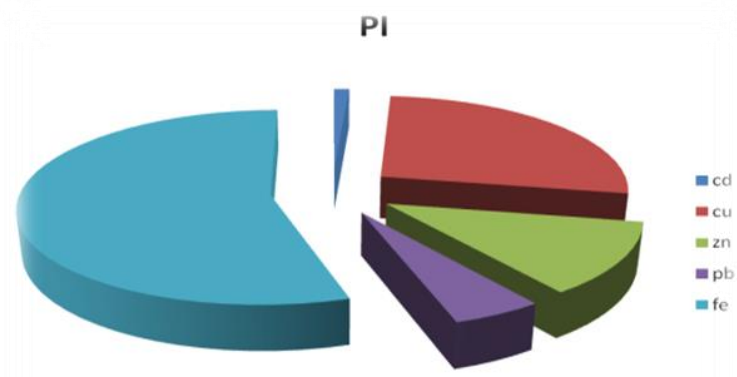

Fig. 3 Sediment contamination index (PI).

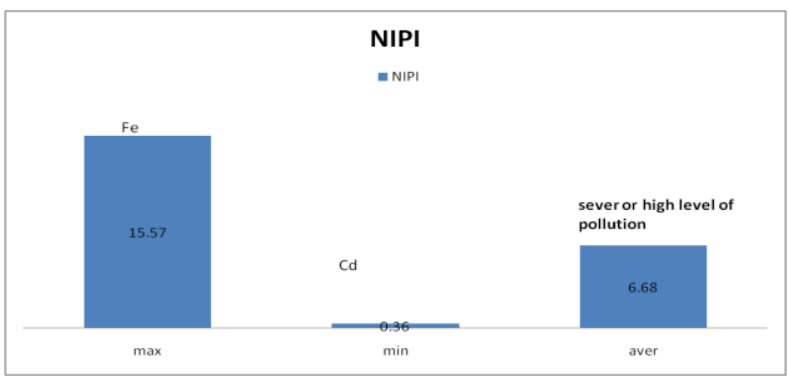

Fig. 4 Integrated pollution index of pollutants in the study area.

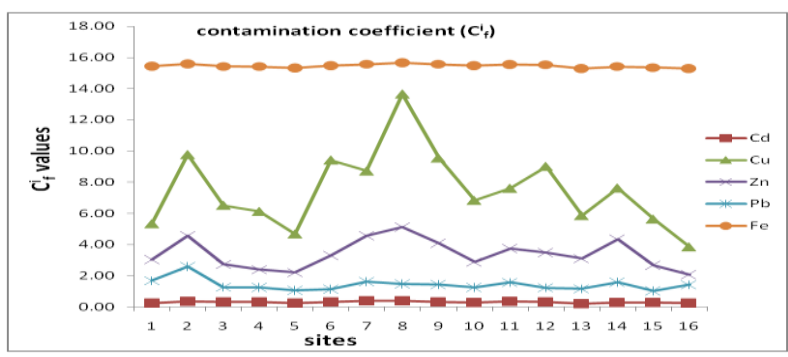

Fig. 5 Sediment contamination coefficient (Cif) in the study sites.

Single and comprehensive potential ecological risk assessment of heavy metals
From the results, we can observe that the scope of the potential ecological risk indices of the four types of heavy metals are $\mathrm{E}_{\mathrm{f}}^{\mathrm{i}}(\mathrm{Cd}) 6.75-12.19, \mathrm{E}_{\mathrm{f}}^{\mathrm{i}}$ $(\mathrm{Cu})$ 19.36-68.29, $\mathrm{E}_{\mathrm{f}}^{\mathrm{i}}(\mathrm{Zn})$ 2.07-5.12, and $\mathrm{E}_{\mathrm{f}}^{\mathrm{i}}(\mathrm{Pb})$ 5.13-13. In terms of the mean potential ecological risk indices of the four types of heavy metals, the $\mathrm{E}_{\mathrm{f}}^{\mathrm{i}}$ arrayed is in the order of $(\mathrm{Cu})>(\mathrm{Cd})>(\mathrm{Pb})>$ ( $\mathrm{Zn}) . \mathrm{Cu}$ was the key influence factor to cause the potential ecological risk, and its mean value of $E_{f}^{i}$ was up to 37.63 with Risk grade (medium). The mean $\mathrm{E}_{\mathrm{f}}^{\mathrm{i}}$ values of $\mathrm{Cd}, \mathrm{Zn}$, and $\mathrm{Pb}$ were 9.47, 3.39 , and 7.13 respectively indicating risk grade (slight) (Fig. 7). The scope of RI was 36.25-92.96 with ecological risk levels slight and strong respectively (Fig. 8). High ecological risks have been estimated to exist in site (8), while the slight ecological risk exists at site (16).

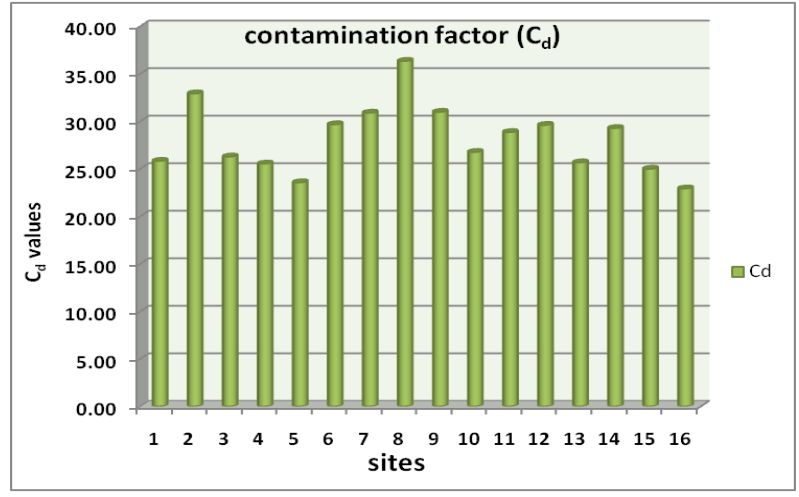

Fig. 6 The degree of pollution $(\mathrm{Cd})$ in the study sites.

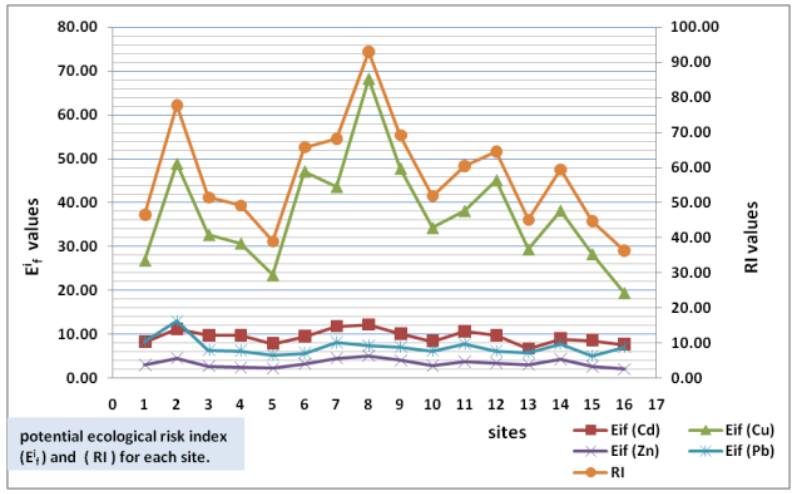

Fig. 7 Single \& comprehensive risk index $\left(E_{R}^{i}, R I\right)$ for each site.

\section{Pearson correlation analysis}

Usually the content of heavy-metal elements originated from the same or similar source tend to have a significant correlation (Hirschfeld, 1935; Rodríguez et al., 2008), so the correlation 
between the heavy-metal content in sediment can be considered as an indicator of whether the source of heavy metal was the same or not. Positive correlation between heavy metals suggests that these heavy metals have common sources, mutual dependence and identical behavior during transport. Negative correlations suggest that they do not share the abovementioned metal traits with each other's (Jiang et al., 2014). The analysis results are listed in Table 8.

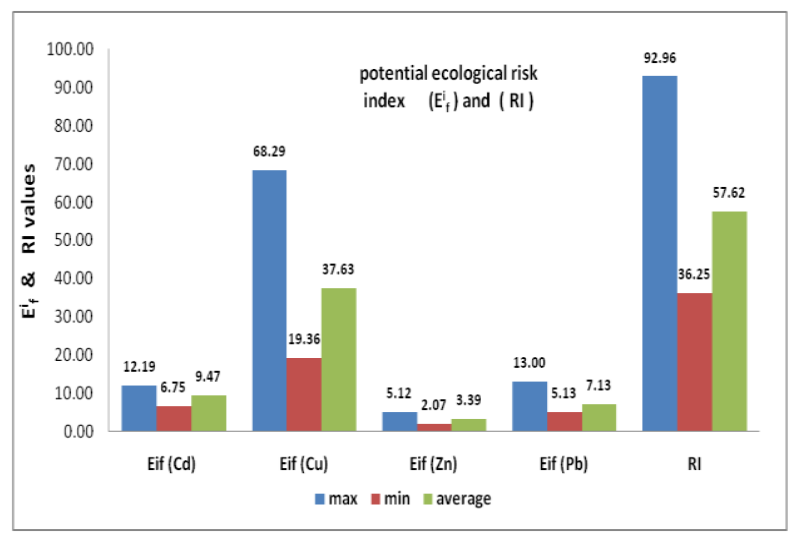

Fig. 8 Min , Max, and Average of the Single \& comprehensive risk index $\left(\mathrm{E}_{\mathrm{R}}^{\mathrm{i}}, \mathrm{RI}\right)$.

Table 8. Pearson's multiple correlations of some heavy metals in sediments of the study area.

\begin{tabular}{cccccc} 
Elements & $\mathrm{Cd}$ & $\mathrm{Cu}$ & $\mathrm{Zn}$ & $\mathrm{Pb}$ & $\mathrm{Fe}$ \\
\hline $\mathrm{Cd}$ & 1.000 & & & & \\
$\mathrm{Cu}$ & $0.793^{* *}$ & 1.000 & & & \\
$\mathrm{Zn}$ & $0.738^{* *}$ & $0.864^{* *}$ & 1.000 & & \\
$\mathrm{~Pb}$ & 0.468 & 0.332 & $0.576^{*}$ & 1.000 & \\
$\mathrm{Fe}$ & $0.882^{* *}$ & $0.886^{* *}$ & $0.822^{* *}$ & $0.501^{*}$ & 1.000 \\
\hline$*=\mathrm{P}<0.05,{ }^{* *}=\mathrm{P}<0.01$ & & & &
\end{tabular}

The results of Pearson correlation analysis indicated that the heavy metals in the sediment are highly correlated with each other, where $\mathrm{Cd}$ is highly correlated with $\mathrm{Cu}, \mathrm{Zn}$ and $\mathrm{Fe}(\mathrm{P}<0.01)$; $\mathrm{Cu}$ with $\mathrm{Zn}$ and $\mathrm{Fe}(\mathrm{P}<0.01)$ and $\mathrm{Zn}$ with $\mathrm{Fe}$ $(\mathrm{P}<0.01) . \mathrm{Pb}$ showed low correlation with $\mathrm{Zn}$ and $\mathrm{Fe}$ in the sediment $(\mathrm{P}<0.05)$.

\section{Conclusions}

The averages of EF were in the range of minor enrichment for $\mathrm{Cd}$ (1.22), $\mathrm{Cu}$ (1.92) and $\mathrm{Zn}$ (1.62) to no enrichment for $\mathrm{pb}(0.99)$ and arranged in order: $\mathrm{Cu}>\mathrm{Zn}>\mathrm{Cd}>\mathrm{Pb}$. The NIPI values in sediments ranged from lightly polluted to severe or high level of pollution with an average of 6.68 (severe or high level of sediment pollution). In terms of the mean potential ecological risk indices of the four types of heavy metals, the $\mathrm{E}_{\mathrm{f}}^{\mathrm{i}}$ arrayed is in the order of $\mathrm{Cu}>\mathrm{Cd}$ $>\mathrm{Pb}>\mathrm{Zn}$. $\mathrm{Cu}$ was the key influence factor to cause the potential ecological risk, and its $\mathrm{E}_{\mathrm{f}}^{\mathrm{i}}$ mean value was up to 37.63 with Risk grade (medium). The scope of RI range was 36.2592.96 with ecological risk levels slight and strong respectively. Strong ecological risk have been estimated to exist in site (8), while the slight ecological risk exists at site (16). The three indices revealed similar levels of heavy metal pollution, indicating that the sites are contaminated by the heavy metals to varying degrees compared to the background values.

\section{References}

Abdel-Baky, T. E., Hagras, A. E., Hassan, S. H., and Zyadah, M. A., 1998. Environmental impact assessment of pollution in Lake Manzala, IDistribution of some heavy metals in water and sediment. J. Egypt. Ger. Soc. Zoo., 26 (B): 25-38.

Ahmed, M. H., El Leithy, B. M., Thompson, J. R., Flower, R. J., Ramdani, M., Ayache, F., and Hassan, S. M., 2009. Application of remote sensing to site characterisation and environmental change analysis of North African coastal lagoons. Hydrobiologia. doi:10.1007/s10750-008-9682-8.

Bai, J., Cui, B., Chen, B., Zhang, K., Deng, W., Gao, H., and Xiao, R., 2011.Spatial distribution and ecological risk assessment of heavy metals in surface sediments from typical plateau lake wetland. China Ecol. Modell. 222, 301-306.

Caeiro, S., Costa, M.H., and Ramos, T.B., 2005. Assessing Heavy Metal Contamination in Sado Estuary Sediment: An Index Analysis Approach. Ecological Indicators, 5: 151-169

Çevik, F., Göksu, M.L., Derici, O.B, and Findik, O., 2009. An assessment of metal pollution in surface sediments of Seyhan dam by using enrichment factor, geoaccumulation index and statistical analyse. Environ Monit Assess 152:309-317.

El Banna, M.M. and Frihy, O.E., 2008. Natural and anthropogenic influences in the northeastern coast of the Nile Delta, Egypt. Environmental Geology. doi:10.1007/s00254-008-1434-6.

El-Gharabaw, M.S., Shata, A.M., El-Gammal, I.M., Ibrahim, S.M., and Khalil, KH.M., 2011. Assessment of some heavy metals pollution in Damietta harbor, Egypt. Egyptian journal of aquatic research, 37(3), 221-231.

El-Serehy, A. H., Aboulela, H., Al-Misned, F., Kaiser, M., Al-Rasheid, K., and Ezz El-Din, H., 
2012. Heavy metals contamination of a Mediterranean Coastal Ecosystem, Eastern Nile Delta, Egypt. Turkish Journal of Fisheries and Aquatic Sciences 12: 751-760.

Fan, C., Zhu, Y., and Ji, Z., 2002. Characteristics of the Pollution of Heavy Metals in the Sediments of Yilihe River, Taihu Basin. Journal of Lake Science., 14(3):235-241.

Fiori, C.S., Rodrigues, P.A., Santelli, E.R., Cordeiro, C.R., Carvalheira, G.R., Araújo, C.P., Castilhos, C.Z., and Bidone, D.E., 2013. Ecological risk index for aquatic pollution control: a case study of coastal water bodies from the Rio de Janeiro State, southeastern Brazil. Geochimica Brasiliensis 27(1): 24-36.

Fu, C., Guo, J., Pan, J., Qi, J., and Zhou, W., 2009. Potential Ecological Risk Assessment of Heavy Metal Pollution in Sediments of the Yangtze River Within the Wanzhou Section, China. Biol Trace Elem Res (2009) 129:270-277.

Ghrefat, H., and Yusuf, N., 2006. Assessing Mn, Fe, $\mathrm{Cu}, \mathrm{Zn}$ and $\mathrm{Cd}$ pollution in bottom sediments of Wadi Al-Arab Dam, Jordan. Chemosphere 65:2114-2121.

Gonzáles-Macías, C., Schifter, I., Lluch-Cota, D.B., Méndez-Rodríguez, L., and Hernández-Vázquez, S., 2006. Distribution, enrichment and accumulation of heavy metals in coastal sediments of Salina Cruz Bay, Mexico. Environ Monit Assess 118:211-230.

Guo, W., Liu, X., Liu, Z., and Li, G., 2010. Pollution and Potential Ecological Risk Evaluation of Heavy Metals in the Sediments around Dongjiang Harbor. Tianjin. Procedia Environmental Sciences 2 (2010) 729-736.

Hakanson, L., 1980. An ecological risk index for aquatic pollution control-a sediment ecological approach. Water Res 14:975-1001.

Hirschfeld, H. O., 1935. A connection between correlation and contingency, Math. Proc. Cambridge, 31, 520-524, doi:10.1017/S0305004100013517.

Jain, C.K., Gupta, H., and Chakrapani, G.J., 2008. Enrichment and fractionation of heavy metals in bed sediments of river Narmada, India. Environ. Monit. Assess. 141, 35-47.

Jiang, X., Lu1, W. X., Zhao, H. Q., Yang, Q. C., and Yang, Z. P., 2014. Potential ecological risk assessment and prediction of soil heavy-metal pollution around coal gangue dump. Nat. Hazards Earth Syst. Sci., 14, 1599-1610.

Kwokal, Z., Frančišković-Bilinski, S., Bilinski, H., and Branica, M., 2002. A comparison of anthropogenic mercury pollution in Kastela Bay (Croatia) with pristine estuaries in Ore (Sweden) and Krka (Croatia). Mar Pollut Bull 44:11521169.

Li, F., Zeng, X., Wu, C., Duan, Z., Wen, Y., Huang, G., Long, X., Li, M., and Xu, J., 2013. Ecological Risks Assessment and Pollution Source
Identification of Trace Elements in Contaminated Sediments from the Pearl River Delta, China. Biol Trace Elem Res (2013) 155:301-313, DOI 10.1007/s12011-013-9789-2.

Li, J., Xie, Z., Xu, J., Ye, L., and Liu, X., 2003. Evaluation on environmental quality of heavy metals in vegetable plantation soils in the suburb of Hangzhou, Ecology and Environment, 12(3), 277-280.

Li, R.Z., Pan, C.R., Xu, J.J., Ding, G.Z., and Zou, Y., 2012. Application of Potential Ecological Risk Assessment Model Based on Monte Carlo Simulation, Res. Environ. Sci., 25, 1336-1343.

Liang, S., Wang, X., Zheng, X., and Sun, H., 2012. Pollution Characteristics and Potential Ecological Risk of Heavy Metals in Water and Sediment of Baiyangdian Lake. Asia Pacific Conference on Environmental Science and Technology Advances in Biomedical Engineering, Vol.6. pp (43-47).

Lourĩno-Cabana, B., Lesven, L., Charriau, A., Billon, G., Baghdad, O., and Boughriet, A., 2011. Potential risks of metal toxicity in contaminated sediments of Deûle river in Northern France. J Hazard Mater 186:2129-2137.

Madkour, G.A., 2005. Environmental Studies on the Biodiversity and Pollution at the Eastern Delta Coast. M. Sc. Thesis, faculty of sciences, Mansoura University.

Persaud, D., R., Jaagumagi, A., and Hayton, 1990. The provincial sediment quality guidelines. Ontario Ministry of the Environment.

Puente, A., Juanes, J.A., and García, A., 2008. Ecological assessment of soft bottom benthic communities in northern Spanish estuaries. Ecological Indicators 8(4):373-388.

Qingjie, G., Jun, D., Yunchuan, X., Qingfei, W., and Liqiang, Y., 2008. Calculating Pollution Indices by Heavy Metals in Ecological Geochemistry Assessment and a Case Study in Parks of Beijing. Journal of China University of Geosciences, Vol. 19, No. 3, p. 230-241, June 2008 ISSN 1002-0705 Printed in China.

Ra, K., Kim, J., Hong, S. H., Yim, U. H., Shim, W. J., Lee, S., Kim, Y., Lim, J., Kim, E., and Kim, K., 2014. Assessment of Pollution and Ecological Risk of Heavy Metals in the Surface Sediments of Ulsan Bay, Korea. Ocean Sci. J. (2014) 49(3):279289. http://dx.doi.org/10.1007/s12601-014-0028-3.

Rasmussen, E. K., Petersen, O S., Thompson, J. R., Flower, R. J., and Ahmed, M. H., 2009. Hydrodynamic-ecological model analyses of the water quality of Lake Manzala (Nile Delta, Northern Egypt). Hydro biologia (2009) 622:195220.

Rodríguez, J. A., Nanos, N., Grau, J. M., Gil, L., and López- Arias, M., 2008. Multiscale analysis of heavy metal contents in Spanish agricultural topsoils, Chemosphere, 70, 1085-1096, doi: 10.1016/j. chemosphere.2007.07.056. 
Saeed, M.S, and Shaker, M. I., 2008. Assessment of heavy metals pollution in water and sediments and their effect on Oreochromis Niloticus in the northern Delta Lakes, Egypt.8th International Symposium on Tilapia in Aquaculture 2008, pp 475-490.

Shaheen, A. H., and Yosef, S. F., 1979. The effect of the cessation of Nile flood on the fishery of Lake Manzala, Egypt. Archiv fur Hydrobiologie 85: 166-191.

Soldecilla, M., Maranon, T., and Cabrera, F., 1992. Heavy-metal content in soil and plants from a pyrite mining area in Southwest Spain, Communications in Soil and Plant Analysis, 23(11-12), 1301-1319.

Suresh, G., Sutharsan, P., Ramasamy, V., and Venkatachalapathy, R., 2012. Assessment of spatial distribution and potential ecological risk of the heavy metals in relation to granulometric contents of Veeranam lake sediments, India. Ecotoxicol. Environ. Saf. (2012), http://dx.doi.org/10.1016/j.ecoenv.2012.06.027.

Taylor, SR., 1964. Abundance of chemical elements in the continental crust: a new table. Geochim Cosmochim Acta 28:1273-1285.
UNEP/IAEA., 1986: References Methods for Marine Pollution Studies. PERSGA- UNECO. 39. University, Egypt.

Wang, J., Liu, W., Yang, R., Zhang, L., and Ma, J., 2013. Assessment of the potential ecological risk of heavy metals in reclaimed soils at an opencast coal mine. Disaster Advances, Vol. 6 (366-377).

Yang, Z. P., Lu, W. X., Long, Y. Q., and Liu, X. R., 2010. Prediction and precaution of heavy metal pollution trend in urban soils of Changchun City, Urban Environ. Urban Ecol., 23, 1-4,.

Yang, Z. P., Lu, W. X., Long, Y. Q., Bao, X. H., and Yang, Q. C., 2011. Assessment of heavy metals contamination in urban topsoil from Changchun City, China, J. Geochem. Explor., 108, 27-38.

Yin, H., Gao, Y., and Fan, C., 2011. Distribution, sources and ecological risk assessment of heavy metals in surface sediments from Lake Taihu, China. Environ. Res. Lett. 6,044012 (11pp).

Zhang, W., Feng, H., Chang, J., Qu, J., Xie, H., and Yu, L., 2009. Heavy metal contamination in surface sediments of Yangtze River intertidal zone: an assessment from different indexes. Environ Pollut 157:1533-1543.

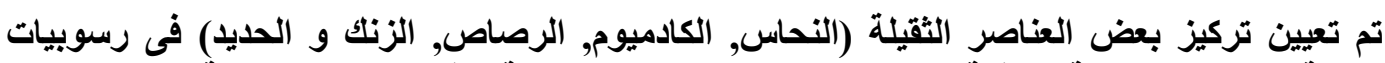

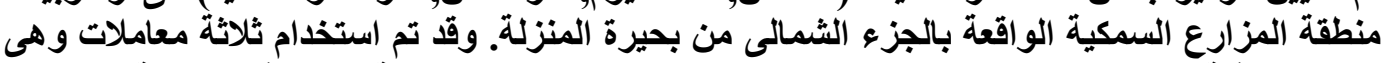

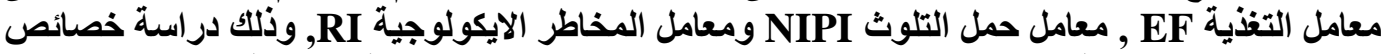

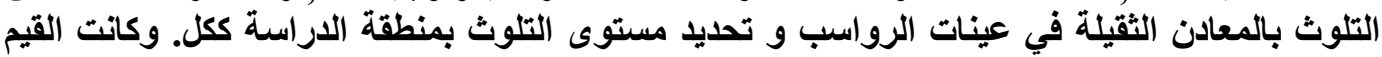

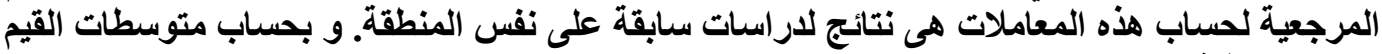

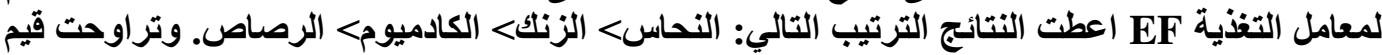

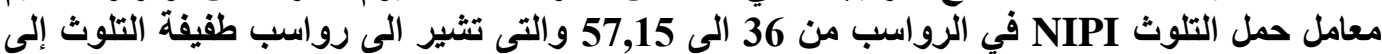

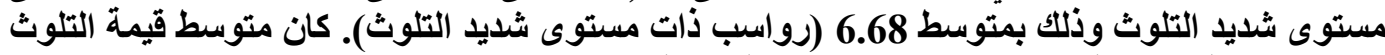

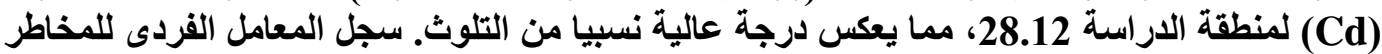

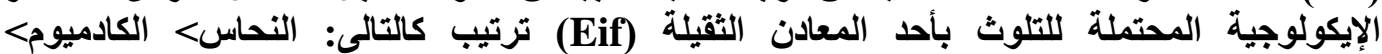

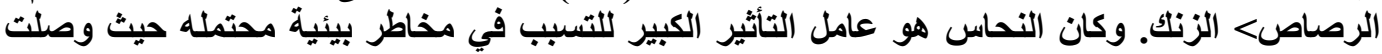

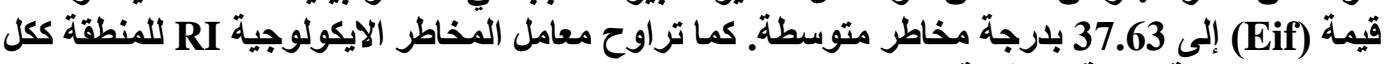

